\title{
AN ASSET VALUE EVALUATION FOR DOCKING FINANCE LEASE PROBLEMS IN THE PEER-TO-PEER PLATFORM
}

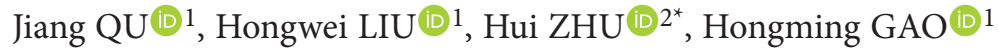 \\ ${ }^{1}$ School of Management, Guangdong University of Technology, Guangzhou, China \\ ${ }^{2}$ School of Management, Guangzhou University, Guangzhou, China
}

Received 11 September 2019; accepted 25 April 2020

\begin{abstract}
The convenience and rapidity of financial leasing modes in the peer-to-peer (P2P) platform enable small and medium-sized enterprises (SMEs) to solve financing problems. The core of risk management in the $\mathrm{P} 2 \mathrm{P}$ platform is to improve the quality of the docking assets. Therefore, the purpose of this paper is to establish a financial leasing value model of debt cession with an optimal economic pattern and an analysis of the risk assessment to improve the management of the asset value docking quality of both parties. For the transaction price of the leased assets in a P2P platform, this paper establishes multi-periodic, continuous, and variable models of the leased assets value evaluation, taking rent, lease term, and interest as independent variables. The paper proves that the price of the leased assets is related to the interest force, the rent per period, and the numbers of payments and changes in rent when other factors remain unchanged. Our results prove that the risk of the P2P platform docking finance lease and the transfer of the creditor's rights investment mode are low. The proposed scheme is verified through hypothesis testing and model simulation. When the lease term is longer and the interest rate is higher, the difference between the two function surfaces is larger. Thus, the business model of financial leasing in the $\mathrm{P} 2 \mathrm{P}$ platform has more obvious business advantages. It provides better business macro direction and business micro-management guidance for the leasing industry, P2P platforms and financial leasing companies.
\end{abstract}

Keywords: P2P platform, financial leasing, asset value evaluation, finance lease docking, risk management.

JEL Classification: G12.

\section{Introduction}

In economic theory, the reason for the existence of manufacturing enterprises is to expand the scales of the enterprises and maximize their profits, both of which require the support of capital production factors. Because of the small scales of these enterprises and the many uncertainties they face, it is difficult for small and medium-sized enterprises (SMEs) to meet the requirements of bank lending. The online peer-to-peer (P2P) loan platform can enable

*Corresponding author. E-mail: zhuhui@gazhu.edu.cn

Copyright (c) 2020 The Author(s). Published by Vilnius Gediminas Technical University

This is an Open Access article distributed under the terms of the Creative Commons Attribution License (http://creativecommons. org/licenses/by/4.0/), which permits unrestricted use, distribution, and reproduction in any medium, provided the original author and source are credited. 
enterprises to collect small amounts of funding for personal savings decision-making funds to enterprises, which solves the problem for enterprises that need to obtain capital and production materials in the form of money. Since the financing requirement is simple and the lending period is short, this can solve the financing difficulties of SMEs (Chen et al., 2016; Freedman \& Jin, 2017). However, investors and borrowers are directly docked by the P2P platforms, and credit data and models are not used to identify the quality of investment targets. If a particular platform suffers from problems such as low quality of docking assets, poor fund management, and mismatched borrowing, the platform will have so much risk when the borrowers default on their repayments that it becomes difficult to redeem the investor's principal and income cash. Therefore, to improve the quality of P2P docking assets, supervision during the capital recovery period and liquidity management are the keys to operating the finance leases in P2P platforms (Gao et al., 2018).

Financial leasing combines financing with leases and has the characteristics of innate profitability, security, and liquidity of financial instruments. As a factor of production and real assets, leasing goods not only solves the problem of minor enterprises expanding their scales of reproduction as demanders, financiers, and lessors of means of production but also provides stable rental income sources for lessors. This business mode both solves the problem that SMEs encounter in expanding reproduction as the financing parties and lease holders and provides the lessors with the sources of the stable rental income. In addition, the leased assets depend on physical property assets that include real physical property as well as controllable risks.

Based on the theory of economics when the P2P platforms are able to link up with high-quality assets, this can result in securitizing the assets of financial leasing companies. This can also design the tenant repayment period in accordance with the liability terminal financial period and transfer the creditor's rights and rental income rights to all Internet investors through this platform (Lin et al., 2017) as well as assisting with the decision-making regarding personal savings on the platform. This model can expand the lessees' production scales, solve the problem of financing companies' large investment scales, and recover the funds occupied by the leased assets in advance. In addition, it can centralize financial capital through the P2P platform to solve the problem of high one-time investment costs and difficult recovery of the funds of the leased assets. And this model creates value for investors and for the platform itself. Indeed, this economic model has recently become a new business paradigm for securitizing financial leasing assets. The business paradigm is discussed in detail in Section 1.1.

According to microeconomics, market transactions need cost expenditure; the financial leasing mode is a complex synthesis because many variables are involved in the business operation. In recent years, many scholars have investigated the factors that influence the financial leasing business, such as lease terms, rental prices, and interest rates. However, the literature contains few works that address financial leasing business modes in the P2P platforms. In terms of symbiotic factors, there is little research on the transaction price of financial leased assets under different business scenarios. In addition, very few works in the literature cover the relationship between the price function and value function of the leased assets. 
Therefore, this paper establishes the value function of the leased assets in terms of symbiotic factors and analyzes the manifestation of the transaction price of the leased assets under different scenarios as well as the difference between the functions for the value of the leased assets and the price of leased goods. Through economic hypothesis and demonstration, this paper proves that the risk level of asset docking and the creditors' rights transfer of financial lease are significantly lower than that of a traditional mortgage. The risk level is determined by the differences between the value function, the price function, and the symbiotic variables. Through empirical numerical simulation and graphical simulation, the paper confirms the difference between the value function of the leased assets and the leased items and concludes that the P2P docking financial leasing business has advantages. The paper also confirms that the risk level of docking financing lease assets and transferring creditors' rights is significantly lower than when the traditional model is used. The risk level is determined by the differences between the value function, the price function, and the symbiotic variables.

The structure of this paper is as follows. It begins by analyzing the variables that affect the financial leasing business and reviewing the related literature. The paper summarizes the research status of the financial leasing business and its factors and establishes the value model of the leased assets. First, the paper analyzes the variables of financial leasing business transactions, summarizes the relevant literature, along with the current situation of the financial leasing business and the factors that influence it, and establishes the value model of financial the leased assets. The second part of the paper involves a systematic review of the modes of the financial leasing business and analysis of the differences between them. This paper puts forward the hypothesis that the P2P docking financial lease has the advantage of factor market supply. Third, according to the characteristics of the Internet financial leasing business on the P2P platform and company theory, this paper proposes that financial leasing transactions are related to transaction frequency and uncertainty and establishes the value function of the leased assets under the multi-cycle, continuous, and variable modes. The fourth part of the paper analyzes the difference between the value of the leased assets and the economic model of the price of the leased items, establishes a risk difference measurement model, and proves by using static and dynamic analysis methods that the docking financial leasing business on the P2P platform has the advantage of risk control. Finally, using data on social experiences and economic intuition, this paper simulates the business scenario under the condition of multi-factor coexistence, verifies the correctness of the hypothesis, and expounds its theoretical significance and practical contribution.

\section{Literature review}

Leasing falls into an ancient economic category. The earliest records of leasing activities date back to 1,400 B.C., when the Phoenicians, who lived along the Mediterranean coast, invented the new business model of leasing. However, even though the use of financial leasing began in the $14^{\text {th }}$ century, it emerged as a new type of transaction mode that was born in the United States in the 1950s. It developed rapidly and became one of the most important means of financing in the world. The emergence of modern financial leasing is the inevitable result of the deepening development of modern asset leasing, which in turn the resulted from the broader scale of the socialized large-scale production division of labor under the conditions 
of the market economy and the essence of free competition in the market economy (Janda \& Svárovská, 2010). Any relationship that modern financial leasing has to that of the previous development period in the rental industry is a leap, since current financial leasing has distinct characteristics. One of these features is that the modern lease is the important symbol of the leasing credit form. Not only does the lessee obtain items to use but of greater importance is the fact that the leasing credit is a means of financing. The development of financing leases as the main body of modern leasing was based on bank and commercial credit by way of independent credit and has the added functions of credit and trade. Also, credit leasing agencies marked the emergence of the leasing company, causing the leasing credit form to take a qualitative leap, with the lessor and the lessee being in passive situations within the rental market. Because of third-party services, leasing companies were able to improve the relationship between the manufacturer and the lessee, and the lessee could determine the purchase option, including the lease it purchased, its renewal, and the return of the asset choice. In addition, the rental market channels, through the leasing company financing and by being able to melt together, allowed the tenant companies to acquire the rights to the use of the asset at the same time, as well as to obtain the necessary funds for the business. Finally, the leasing is more effective and the economic relationship is more complex and extensive.

Finance leasing businesses achieve transactions through inter-enterprise economic contracts. The transaction process includes purchasing the leased assets, leasing and using assets, and paying rent regularly. The variables involved in the contract transaction prices are as follows. The first is the price of the asset, which includes the purchase price of the rental asset as well as the depreciation method and value after depreciation. The second variable is interest. The financial leasing company needs to raise funds to purchase the underlying assets. Once the asset has been leased, the lessee needs to pay the interest. The third variable is the value of the asset. This involves mainly the transfer of a creditor's right and the right of return of the leased assets. The fourth variable is the rent. The lessee needs to pay the funds regularly to the financial leasing company, in accordance with the method that was agreed upon. The final variable is the term of lease; that is, the cycle of asset rental and rental payment that the parties in the financial leasing business agreed on, and the longer the cycle, the higher the interest cost paid by the lessee.

\subsection{The business mode of financial leasing in the P2P platform}

With the continuous progress and development of the Internet, leasing in the P2P platform has become a new financial means. However, the financial leasing business model is complicated. The leasing company mortgages the leased property to the P2P platform after docking the financial leasing business (Guo et al., 2016). The rental and interest income that the leasing company collects is the investment return of the investors in the platform, and the investment return cycle is determined according to the rent payment cycle. Thus, factors such as the price of a lease, the price of a lease after depreciation, the rent, the interest, the payment cycle and debt repayment period, and the lease term are all involved in the financial leasing business in the P2P platform (Zhang \& Chen, 2017). In addition, the business paradigm of financial leasing in the $\mathrm{P} 2 \mathrm{P}$ platform has been changing in recent years. We introduce three major business models as follows. 


\subsubsection{The traditional mode in the $\mathrm{P} 2 \mathrm{P}$ platform}

Many scholars (Bachmann et al., 2011; Wang et al., 2009; Galloway, 2009) studied the impact of the P2P program on the traditional credit industry. The basic mode is that people are registered personally as investors in these platforms, and the SMEs or borrowers release their borrowing information to investors on the platform. The investors then bid for the borrowing target and deposit the funds through the withholding methods used by the particular bank. After the platform is confirmed, the bank transfers the loan to the borrower. During the investment period, the borrower regularly deposits the loan principal and interest into the bank, and the bank transfers these to the investor, as shown in Figure 1.

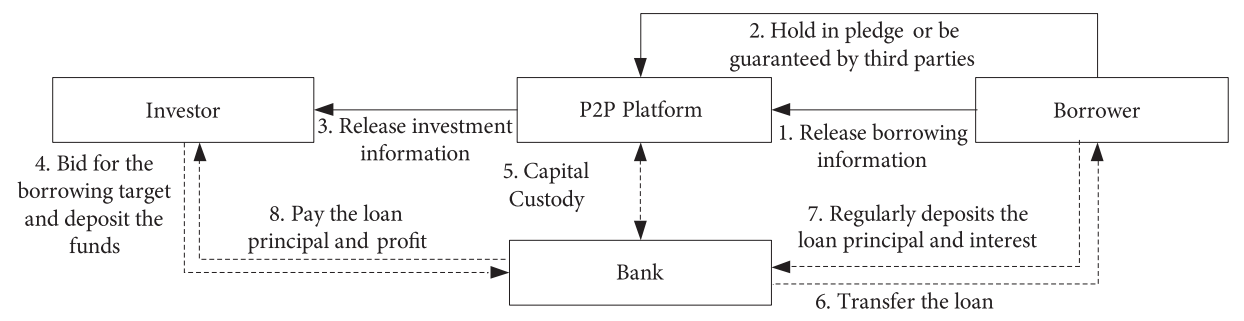

Figure 1. The traditional mode in the P2P platform

\subsubsection{The financial lease mode of the assignment of proceeds in the P2P platform}

This mode is an extension of the traditional P2P mode. The lessee finances assets to the financial leasing company (Fenwick et al., 2018) as a platform borrower and the financial leasing company transfers the rental income right of the lease to the investor, with the price calculated by using the method of hypothecation in the P2P platform. The investor pays the consideration funds for assignment of the proceeds, and the funds withholding and disbursement are done by the bank. The financial leasing company borrows the funds and obtains the spread between the investors and the rental income. The platform is responsible for assessing the benefits and risks of the project and showing investors the transfer of rental income rights. Leasing projects are evaluated by financial leasing companies, as shown in Figure 2.

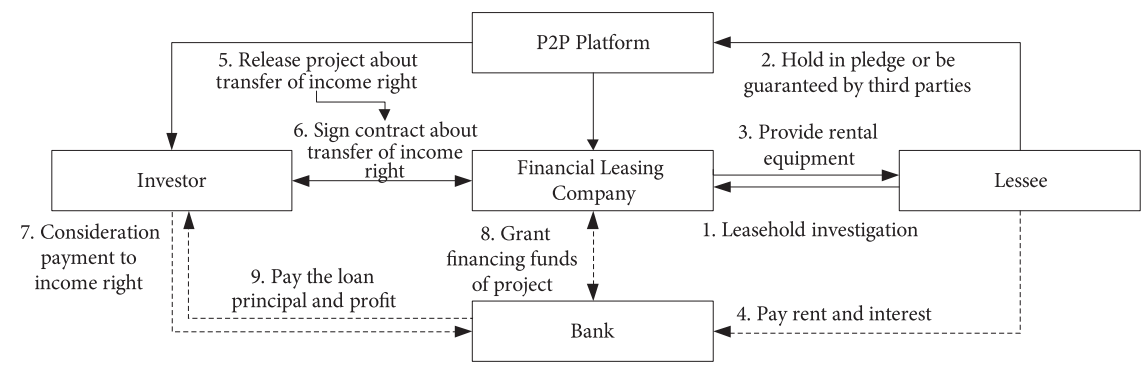

Figure 2. Financial lease mode of the assignment of proceeds in the P2P platform 


\subsubsection{The financial lease mode of debt cession in the P2P platform}

As a borrower, the financial leasing company releases the project with the transfer of leasehold assets in the platform. Figure 3 is showing that the P2P platform fully evaluates the benefits and risks of the project and checks the qualification and management abilities of the financial leasing company. Also, in this platform, the investment project is demonstrated to investors. The investor can choose the project and sign the contract for the transfer of the creditor's rights with the financial leasing company and then become the new creditor to the lessee. The lessee keeps the right to use the leased assets and regularly pays the rent to the bank. The profits of the investment that go to the investor are paid by the bank.

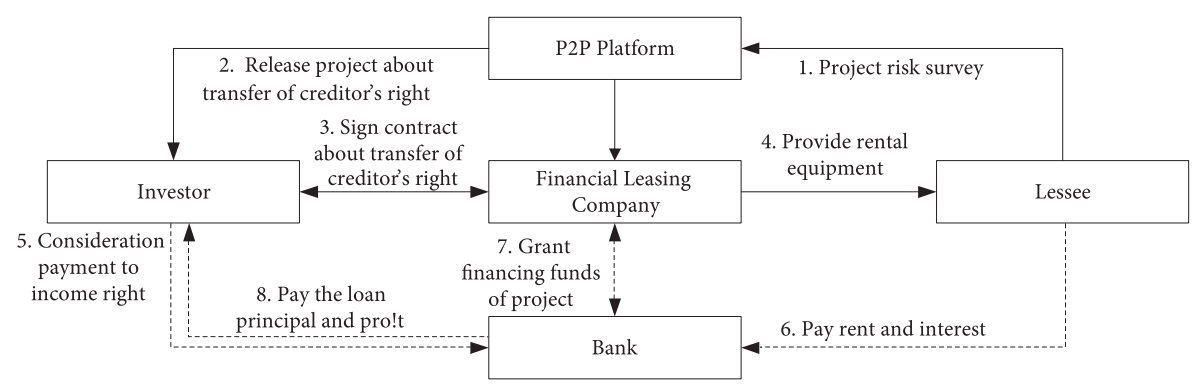

Figure 3. Financial lease mode of debt cession in the P2P platform

Proposition 1: The Financial Lease Creditor's Rights Transfer Model performs best in the Economic Pattern.

Under these three modes, production enterprises and financial leasing companies can obtain financing and production elements through the platform. By contrast, within the traditional mode and the income distribution mode, the borrower obtains the platform only through a mortgage to raise funds. In economics, the transaction cost is raised because of the high degree of asset specificity of the platform docking in the transaction. The mode of the assignment of proceeds relies on the flow of the repayment fund that is provided by the rent receivable as a guarantee to obtain funds. The debt relationship of each of the platform's trading entities remains unchanged, and there are many uncertain factors in the transaction, which also increases the transaction risk of the platform. However, because savings investors only have investment transaction contracts and do not hold the relationship between proprietary assets and debt, the limited rationality of the investors will limit the decision-making regarding savings, thus restricting the supply of platform capital.

Under the mode of debt cession, the platform obtains funds through assets transactions rather than through collateral and cash receivables. It also reduces the amount of exclusive use of assets and transaction costs. However, by focusing on assets transactions the financial leasing company divides the investment project into fixed income products and transfers them to investors through the Internet and P2P platform so that it can make capital available in advance and liquidize remnant assets. The platform will assess project risk and carry out asset pricing in the company to avoid risk (Ferreira et al., 2013). By acquiring the transfer creditor's rights, investors improve their bounded rationality and promote the conversion of current consumption into platform savings, the summary is documented in Table 1. 
Table 1. A comparison of business modes in the P2P platform

\begin{tabular}{|l|l|l|l|}
\hline \multicolumn{1}{|c|}{ Business Mode } & \multicolumn{1}{|c|}{ Investor } & \multicolumn{1}{c|}{ P2P Platform } & \multicolumn{1}{c|}{ Docking Assets } \\
\hline $\begin{array}{l}\text { The Traditional } \\
\text { Mode in the P2P } \\
\text { Platform }\end{array}$ & $\begin{array}{l}\text { Investors connect } \\
\text { directly with borrowers } \\
\text { on the platform and } \\
\text { the risk is aggregated } \\
\text { by borrowers. }\end{array}$ & $\begin{array}{l}\text { The platform acts as an } \\
\text { intermediary and does } \\
\text { not touch the funds but } \\
\text { only collects interest } \\
\text { rates. }\end{array}$ & $\begin{array}{l}\text { The borrower provides a } \\
\text { third-party guarantee or } \\
\text { mortgage pledge. }\end{array}$ \\
\hline $\begin{array}{l}\text { The Mode of the } \\
\text { Assignment of } \\
\text { Proceeds }\end{array}$ & $\begin{array}{l}\text { Investors choose } \\
\text { a project on the } \\
\text { platform and pay the } \\
\text { consideration funds } \\
\text { for the assignment of } \\
\text { proceeds }\end{array}$ & $\begin{array}{l}\text { The platform reviews } \\
\text { the qualifications } \\
\text { of financial leasing } \\
\text { companies and assesses } \\
\text { the balance of benefits. }\end{array}$ & $\begin{array}{l}\text { Financial leasing companies } \\
\text { regularly provide repayment } \\
\text { funds flow based on } \\
\text { receivable rents to provide } \\
\text { a guarantee or mortgage } \\
\text { pledge. }\end{array}$ \\
\hline $\begin{array}{l}\text { The Mode of Debt } \\
\text { Cession }\end{array}$ & $\begin{array}{l}\text { Investors sign the } \\
\text { contract about debt } \\
\text { cession with the } \\
\text { financial leasing } \\
\text { company on the } \\
\text { platform. }\end{array}$ & $\begin{array}{l}\text { The platform audits the } \\
\text { lease contract, assesses } \\
\text { the risk, investigates } \\
\text { the leased property, } \\
\text { and conducts asset } \\
\text { pricing. }\end{array}$ & $\begin{array}{l}\text { Asset securitization, asset } \\
\text { transaction, and debt } \\
\text { cession are carried out. }\end{array}$ \\
\hline
\end{tabular}

\subsection{The symbiotic variables of financial leasing in the $P 2 P$ platform}

From the theory of the firm, which includes market transactions and transaction prices, many scholars have learned about variables such as the lease terms, rental prices, and interest rates that affect the financial leasing business. According to the research about financial leasing business models and strategies, Dai et al. (2016) solved an online version of a financial leasing decision problem by using the competitive analysis method for choosing leases or financial leases when the lessees do not know how long they will use the asset. Dai et al. (2016) also proposed optimal online strategies and simple decision-making rules.

In the research about lease term $n$, Karp (1992) proposed the "ski-rental" model to analyze the optimal strategy for lessees with regard to when they should choose to rent or buy something by first using the online version and competitive analysis method. Taking interest rate $i$ into consideration, El-Yaniv et al. (1999) studied the optimal online strategy of the "ski-rental" problem, while Yang et al. (2012) discussed the optimal deterministic algorithm and the stochastic algorithm of the generalized ski-rental problem. Also, taking time as the variable, some scholars studied the factors affecting interest rates from both the microscopic and microcosmic angles of the term structure of interest rates to study the change in the asset price.

In relation to the study of rent $R$ and the price of the leased assets $A$, Lotker et al. (2018a; $2018 \mathrm{~b}$ ) proposed the multi-slope ski-rental problem and the multiple discount option ski-rental problem. El-Yaniv and Karp (1997) and Azar et al. (1999) analyzed the related scenarios according to the changes in suppliers and the requirements of the assets by tracing the suppliers and the market.

In terms of the research about the value of an asset $P$, Milanesi (2016) studied the lease contracts using real options with different levels of simplicity and complexity. Milanesi (2016) also examined the ultimate value of the assets of the contracts under different modes, such as 
buy, anticipated cancel, renew, exclusive renew-buy, and deferred payment. Liang et al. (2012) studied typical creative financial leasing, including venture lease, percentage lease, lease with deferred payment, and cancellable lease, and proposed a method of decomposition and a diagram method as well as the complex real options, all expressed as a portfolio of vanilla options and simple exotic options.

With respect to the operation of the P2P platform, Herrero-Lopez (2009) and Sonenshein et al. (2011) analyzed the relevant factors that affect the platform's operational efficiency. Larrimore et al. (2011) and Lin et al. (2013) examined the factors required for successful borrowing. In terms of behavioral and social factors, Ceyhan et al. (2011) studied the influences of economic and social factors and herding behavior on bidding, building a model based on the bidding process to predict the success of a loan request and whether a loan would be repaid or not. With the dynamic and sequential characteristics of listings, Zhao et al. (2018) looked at the market state model and analysis for online P2P lending. The information gathering and decision making of investors in the platform have also been studied by many scholars (Puro et al., 2011; Ceyhan et al., 2011; Herzenstein et al., 2011; Lee \& Lee, 2012). From the perspective of information economics, Yan et al. (2015) examined the credit risk management of the P2P program based on big data technology to reduce the cost of information and searching.

The literature noted above studied every factor affecting the financial leasing business, including when the lessee would buy, the randomness, the interest rates, the asset prices, and the markets. The operational efficiency in the P2P platform, the behavioral factors of the platform parties, the social factors, and the market shave also been studied. However, these previous studies looked at financial leasing mainly from the perspective of the lessee, relying on multi-scene analysis and the extension of single variables and focusing mainly on the analysis of the factors of successful borrowing, the behaviors of financing parties, and the market environments. Combining all factors in financial leasing is rare when studying the asset securitization of financial leasing, the multi-dimensional function of the value of the leased assets, and the measurements of risk.

Therefore, in this paper, we systematically review the economic model of the financial leasing business and summarize factors that facilitate transactions and influence the business. These factors, such as the interest rate, rent, and terms of the lease, are considered as independent variables in terms of the value of the leased assets. By stimulating the expression of functions under the multi-service scenario, the change of function in the value of the leased assets and the prices of leased items are studied. The model for measuring risk differences is constructed, while the advantages of the docking financial leasing business in the P2P platform are verified.

This paper studies the model for the financial leasing business under the P2P platform from a practical level and puts forward a hypothesis for the optimal economic model. The paper also looks at the changing trend in the process of determining the value function for financial leased assets when the external conditions and variables change. Through data deduction and function simulation, the business scenario is simulated under the condition of multi-factor co-occurrence to verify the correctness of the hypothesis. In terms of theoretical research, financial mathematics is used to verify the mode, to show that the risk of the leased assets that are held through the P2P platform and the debt cession to invest are lower than they are with the traditional mode, which uses mortgage-backed funding by investors while the revenue of the platform remains unchanged. 


\section{Problem definition and notations}

\subsection{The value function of the leased assets}

We abstract the economic phenomena described above into a mathematical model. Based on the assumption that the $\mathrm{P} 2 \mathrm{P}$ platform cooperates with the financial leasing company, as the lessor to this financial leasing business, the initial value of the leased items is $A$ (asset) and the residual value of the leased items is $S$ (salvage). From the perspective of the product's life cycle, the value of the leased items should be equal to their value after depreciation, following the debt cession of the rental leases. This state has now reached the static equilibrium state defined by economics.

The depreciation year is $t(t=1,2, \cdots, k)$ and the annual depreciation amount of the leased items is $D_{\hat{t}}$ (depreciation). After $k$ years, the value of the leased property that the financial leasing company will own after depreciation is $A(t)=\left[A-\sum_{t=1}^{k} D_{\bar{t}}\right]$. At the end of the financial leasing agreement, the accumulated depreciation of the leased items is $(A-S)$.

After the financial leasing company assigns the debt right to the investor through the P2P platform, the lessee returns the rent to the platform and the investor continuously through the bank. In this business, we assume that the value of the leased assets is $P_{n}$ (property) and the time is $t$. The funds $R_{t}$ (rent) paid in each period are assigned to the investor with a rate of return $i . P_{0}$ represents the value of the assets that is agreed on at the beginning of the business, and $P_{t}$ represents the value of the assets when the lessee repays after $t$ periods. When the leasing business is complete, the creditor's rights transfer agreement is concluded. The two parties can renew the lease, hire purchase or return the business according to the assets that are agreed on, based on the residual value of the leased items $S$, which is $P_{0}=(A-S)$ and is equal to the accumulated depreciation of the leased items.

The value of the assets is expressed by the current value of a series of cash flows $R_{t}$ in the future. Assuming that the annualized returns are $i$, the function of assets value can be described as follows:

$$
P_{0}=\sum_{t=1}^{n} R_{t}(1+i)^{-t}=\sum_{t=1}^{n} R_{t} v^{t} .
$$

After the debt cession of the leased assets, the financial leasing company obtains the investment funds. The lessee will pay the rent $R\left(R=R_{t}\right)$ to the investor through the P2P platform at the end of each period. The principle of the payment at the beginning of the period is consistent with the payment at the end of the period. Due to the long terms involved in the leasing business, payment at the end of the period is generally adopted. The function of assets value is as follows:

$$
P_{0}=\sum_{t=1}^{n} R(1+i)^{-t}=R \cdot p_{n i}=R v+R v^{2}+\cdots+R v^{n-1}+R v^{n}=\sum_{t=1}^{n} R v^{t},
$$

where the rate of return on assets $i$ is defined by the platform, referring to the benchmark interest rate for the loan. The term is generally defined according to the useful life of the leased assets to the lessee. 


\subsection{The value function of financial leasing in $P 2 P$}

According to the theory of microeconomics, the transaction frequency and uncertainty in the transaction process will affect the transaction price. Through analysis of the financial leasing business and the creditor's rights transfer mode, this chapter examines the model for the transaction price of the leased assets in general, multi-cycle, continuous, and changing modes.

Proposition 2: With other factors unchanged, the price of the leased assets is related to the interest force, the rent per period, the number of payments, and the amount of the rent change.

\subsubsection{The value function of the leased assets with multi-periodic payment of the rent}

For the Internet financial leasing business, investment and financial business in the P2P platform are different from those that are offline. The platform must consider the liquidity of the funds, the diversity of the financial products, and the diversified requirements of Internet investors, such as a short investment time, low investment quota, and frequent withdrawal of funds from circulation. Therefore, the online business must design a model in which the lessee pays the investor several times each year (for example, quarterly, monthly, or weekly) to meet the liquidity requirement, and this model of asset pricing can be structured according to the general pricing model.

After assigning the creditor's right, we assume that the lessee pays the rents to the investor $m$ times per year. The return on assets is $i^{(m)}$, when $(1+i)=\left[1+\frac{i^{(m)}}{m}\right]^{m}$, and $i^{(m)}$ can be expressed through the annual rate of return as $i^{(m)}=m\left[(1+i)^{\frac{1}{m}}-1\right]$. In addition, the profitability of the investor at the time of the transaction can be described through the relative rate of change of the asset's value function; this is the force of interest $\delta$.

$$
\text { Since } \delta=\frac{\left\{\frac{d\left[R \cdot(1+i)^{t}\right]}{d t}\right\}}{\left[R \cdot(1+i)^{t}\right]}=\ln (1+i) \text { the function for the return on assets above can be }
$$

expressed as $(1+i)^{t}=\left[1+\frac{i^{(m)}}{m}\right]^{m t}=e^{\delta t}$.

Introducing the rate of return in multi-periodic payment $i^{(m)}$ into the function of the current value $p_{\mathrm{ni}}^{(m)}$ results in the following:

$$
p_{\overline{n i}}^{(m)}=\frac{1}{m}\left(v^{\frac{1}{m}}+v^{\frac{2}{m}}+\cdots+v^{\frac{m n-1}{m}}+v^{\frac{m n}{m}}\right)=\frac{1-v^{n}}{m\left[(1+i)^{\frac{1}{m}}-1\right]}=\frac{1-v^{n}}{i^{(m)}} .
$$

In the mode that involves multi-periodic payment of the rent, the function for the value of the leased assets and the rent can be expressed by using the function of return on assets $i^{(m)}$, the force of interest $\delta$, and the current value $p_{n i}^{(m)}$ : 


$$
P_{0}=\sum_{t=1}^{m n} R\left(1+\frac{i^{(m)}}{m}\right)^{-m t}=\sum_{t=1}^{n} R \cdot e^{-\delta t}=R \cdot p_{\overline{n i}}^{(m)}=R \cdot \frac{1-v^{n}}{i^{(m)}}=R \cdot \frac{1-v^{n}}{m\left[(1+i)^{\frac{1}{m}}-1\right]}
$$

\subsubsection{The value function of the leased assets with continuous payment of the rent}

Considering that the lessee pays the rent to investors every day; that is, the assets returns on a daily cycle, $m=365$, we improve the value function of the multi-periodic payment of assets and shorten the cycle to study the real-time income of the leased assets. This model is closer to the liquidity pattern of the continuous transaction time of the Internet platform and the fragmentation of the periodic granularity so that the discussion is also both more theoretical and more practical.

Combined with the continuation property of the function, and improved integral is adopted in the function of the asset value (2):

$$
P_{0 \mid}=R \cdot \bar{p}_{n i}=\int_{0}^{n} R \cdot v^{t} d t=\left.R \cdot \frac{v^{t}}{\ln t}\right|_{0} ^{n}=R \cdot \frac{1-v^{n}}{\delta} .
$$

\subsubsection{The value function of the leased assets with changing payment of the rent}

This method is used when the profit generated by the assets is not high in the early stage of the leasing business transaction, or to increase the liquidity and accelerate the withdrawal of profit in the platform. In actual business, the platform may adopt a variable method for the pricing of the leased assets. Therefore, the model is improved to study the asset value function with the changing rent.

If it is assumed that the change in rent will occur regularly, such as increasing (decreasing) or changing in equal amounts based on the rent $R$, either a fixed value $d$ will be added to the rent ( can be positive or negative) or a ratio $q$ multiplied by the rent in each period. The value function can then be improved as follows:

$$
\begin{gathered}
P_{0}=R \cdot v+(R+d) \cdot v^{2}+\cdots+[R+(n-1) d] \cdot v^{n} ; \\
P_{0}=R v+R q \cdot v^{2}+R q^{2} \cdot v^{3} \cdots+R q^{n-1} \cdot v^{n} .
\end{gathered}
$$

\subsection{Dynamic analysis of the value function of the leased assets}

In this case, the rental assets value function involves a change at different stages. $P_{0}$ is defined as the value of the leasing assets at the initial stage of the business transaction. $P_{1}$ is defined as the value of the leased assets after one periodic rent has been paid by the lessee to the investor. $P_{t}$ is defined as the asset value after $t$ periodic rents have been paid by the lessee to the investor. Considering that the profit $R$ that the investor can acquire from the leased assets in each period contains the principal and interest paid by the lessee, the change in the value of the leased assets of the investor can be obtained by derivation.

For example, after one periodic rent has been paid by the lessee to the investor, the value of the assets can be described as follows:

$$
P_{1}=P_{0}-\left(R-i \cdot P_{0}\right),
$$


where $i \cdot P_{0}$ refers to the interest paid by the lessee to the investor in the first period. $R-i \cdot P_{0}$ denotes the principal of the leased assets paid by the lessee.

Therefore, the function of the change in the value of the leased assets is the following:

$$
\begin{gathered}
P_{2}=P_{1}-\left(R-i \cdot P_{1}\right)=P_{1}(1+i)-R=P_{0}(1+i)^{2}-R[(1+i)+1] ; \\
P_{3 \mid}=P_{2}-\left(R-i \cdot P_{2}\right)=P_{2}(1+i)-R=P_{0 \mid}(1+i)^{3}-R \cdot\left[(1+i)^{2}+(1+i)+1\right] ; \\
P_{t}=P_{t}-\left(R-i \cdot P_{t-1 \mid}\right)=P_{0 \mid}(1+i)^{t}-R\left[(1+i)^{t-1}+\cdots+(1+i)^{2}+(1+i)+1\right] .
\end{gathered}
$$

Also, the value of the leased assets should be equal to the current value of the balance that the lessee should pay to the platform in the future; that is,

$$
P_{t}=R \cdot p_{n-t i} \cdot
$$

The equality of these two expressions can be proven as follows:

$$
\begin{aligned}
& P_{t}=P_{0 \mid}(1+i)^{t}-R\left[(1+i)^{t-1}+\cdots+(1+i)^{2}+(1+i)+1\right]= \\
& R \cdot p_{n i} \cdot(1+i)^{t}-R\left[(1+i)^{t-1}+\cdots+(1+i)^{2}+(1+i)+1\right]= \\
& R \cdot\left[(1+i)^{t} \cdot \frac{1-v^{n}}{i}-\frac{(1+i)^{t}-1}{i}\right]=R \cdot \frac{1-v^{n-t}}{i}=R \cdot p_{\overline{n-t}} .
\end{aligned}
$$

\subsection{The variation trend in the value and price of the leased assets}

\subsubsection{The changing trend in the value of the leased assets}

The following is used to calculate the first and second derivatives, of $P_{t}=R \cdot p_{n-t}$ ii with respect to $t$ in the function of the value of the leased assets of the investor:

$$
\frac{d \cdot P_{t}}{d t}=\frac{d \cdot\left(R \cdot p_{n-t i}\right)}{d t}=\frac{d \cdot\left(R \cdot \frac{1-v^{n-t}}{i}\right)}{d t}=-\frac{R}{i} \ln (1+i) \cdot(1+i)^{-(n-t)}
$$

and

$$
\frac{d \cdot\left(\frac{d \cdot P_{t}}{d t}\right)}{d t} \frac{d \cdot\left(-\frac{R}{i} \ln (1+i) \cdot(1+i)^{-(n-t)}\right)}{d t}=-\frac{R}{i}[\ln (1+i)]^{2} \cdot(1+i)^{-(n-t)} .
$$

From the expressions above, we can see that the first and second derivatives of the changes in the value of the leased assets $P_{t}$ are both less than zero. $P_{t}$ represents monotonous decreasing, and its curve is convex, which means that the decrease in the value of the assets is slow at first but then becomes fast; this is the opposite of the decline in the depreciated value of the leased items. 


\subsubsection{The changing trend in the price of the leased items}

In the financial leasing business, the leased item is usually a large item. However, such leased items reflect their values with accelerated depreciation. In practical life, the sum of the years' digits method with accelerated depreciation is adopted to calculate the depreciated asset price. Depreciation in each term $D_{\hat{t}}$ can be expressed as follows:

$$
D_{\vec{t}}=\frac{n-t+1}{D_{n}}(A-S)
$$

$t$ is lease term, where $t(t=1,2, \cdots, n), D_{n}=1+2+\cdots+n$ are constants while $n$ is the amount of lease term.

From this function, we can determine that when $t$ increases, $D_{\bar{t}}$ generally decreases, and the depreciation is fast at first but then becomes slow. The function of the change in value of the leased items is $A(t)=\left[A-\sum_{t=1}^{n} D_{\vec{t}}\right]$, and this shows that the decline is fast at first but also then becomes slow; that is, the price function of the leased items follows the trend of a concave decline, which is the opposite of the changing trend in the value of the leased assets.

\section{The advantages of the mode of debt cession in P2P financial leases}

Proposition 3: In conditions where the rate of return remains unchanged, the value function of the leased assets is higher than the price value of the leased items in the dynamic process. Finance leasing companies avoid risks through transfer of creditors' rights, or asset securitization, which is lower than that obtained by the mortgage. By extending the lease term or improve the interest rate, the value of the assets is more than the price of leased items, and business risk is further reduced.

$A(t)$ represents the depreciated price of leased items, then if the asset side of the P2P platform is to obtain platform financing through the financing leasing company providing collateral, the price function of collateral for the leased items is $A(t)=\left[A-\sum_{t=1}^{n} D_{\hat{t}}\right]$. If the financial leasing company transfers the rights of the financial leasing creditor to investors through the $\mathrm{P} 2 \mathrm{P}$ program, the corresponding asset value function is $P_{t}=R \cdot p_{n-t \mathrm{i}}$.

Based on the analysis above, we can determine that the initial and final values of the two functions are equal and achieve equilibrium, with the increase in the lease term $t$ and the higher interest rate $i$. However, on the surface, the convex trend is more obvious for the assets value function $P_{t}$, while the concave trend is more obvious for the price function of the leased items $A(t)$. Meanwhile, the value of the price function of the leased items is always lower than that of the value function of the leased assets. With the increase in the lease term $t$ and the higher interest rate $i$, the difference between these two functions becomes greater.

The value of the assets with the creditor's right is higher than the price value of the leased items. The risk of the leased assets held by the P2P platform and the transfer through the creditor's right to invest is lower than for the traditional mode where the P2P platform includes mortgage-backed funding by investors, while the revenue of the platform remains 
unchanged. With the increase in the lease term and the higher interest rate, the difference between the two business models in risk-avoiding will be widened. The risk can be measured by $F(t)=P_{t}-A(t)$, which proves the advantages of the financial leasing business combined with the P2P platform at a theoretical level.

With the shortening of lease term, the difference between the value of the assets and the price of leased items is pulled down, the value of assets is closer to the price of leased items after creditor's right transfer, and the difference of risk aversion between the two business models become narrow. With the increase of the interest rate risk of the assets by transferred bonds, the difference between the two business models in avoiding risks is widened, and the value of the assets transferred by bonds is higher than the price of the leased items. Thus, the business model of financial leasing in the P2P platform has more obvious business advantages.

\section{Simulation}

Based on the above models, we simulated the following case to prove our proposed scheme. The leased items purchased was 100 million RMB, the lease term was 36 (each month is a term), the interval of the interest rate was between $5 \%$ and $10 \%$, and the securitization of the financial leased assets was within three years, the parameters of the simulation function are shown in Table 2.

Table 2. Parameters of the simulation function

\begin{tabular}{|c|c|c|c|c|c|c|c|c|c|c|c|}
\hline Term & $\mathrm{t}$ & 0 & 1 & 2 & 3 & 4 & 5 & 6 & 7 & 8 & 9 \\
\hline $\begin{array}{c}\text { Func- } \\
\text { tion }\end{array}$ & $A(t)$ & 10000 & 9460.00 & 8935.00 & 8425.00 & 7930.00 & 7450.00 & 6985.00 & 6535.00 & 6100.00 & 5680.00 \\
\hline \multirow[t]{10}{*}{$P_{\vec{t}}$} & $1 \%$ & 10000 & 10000 & 9760.20 & 9518.00 & 9273.38 & 9026.32 & 8776.78 & 8524.75 & 8270.20 & 8013.10 \\
\hline & $2 \%$ & 10000 & 10000 & 9800.17 & 9596.35 & 9388.45 & 9176.40 & 8960.10 & 8739.47 & 8514.44 & 8284.90 \\
\hline & $3 \%$ & 10000 & 10000 & 9834.77 & 9664.58 & 9489.28 & 9308.73 & 9122.76 & 8931.21 & 8733.91 & 8530.70 \\
\hline & $4 \%$ & 10000 & 10000 & 9864.36 & 9723.29 & 9576.58 & 9424.00 & 9265.32 & 9100.29 & 8928.65 & 8750.16 \\
\hline & $5 \%$ & 10000 & 10000 & 9889.39 & 9773.25 & 9651.30 & 9523.25 & 9388.80 & 9247.63 & 9099.40 & 8943.76 \\
\hline & $6 \%$ & 10000 & 10000 & 9910.35 & 9815.31 & 9714.58 & 9607.80 & 9494.61 & 9374.64 & 9247.46 & 9112.65 \\
\hline & $7 \%$ & 10000 & 10000 & 9927.73 & 9850.40 & 9767.65 & 9679.12 & 9584.38 & 9483.02 & 9374.56 & 9258.50 \\
\hline & $8 \%$ & 10000 & 10000 & 9942.02 & 9879.40 & 9811.78 & 9738.74 & 9659.86 & 9574.67 & 9482.67 & 9383.30 \\
\hline & $9 \%$ & 10000 & 10000 & 9953.68 & 9903.20 & 9848.17 & 9788.19 & 9722.81 & 9651.55 & 9573.87 & 9489.21 \\
\hline & $10 \%$ & 10000 & 10000 & 9963.14 & 9922.59 & 9877.98 & 9828.92 & 9774.94 & 9715.58 & 9650.27 & 9578.43 \\
\hline Term & $\mathrm{t}$ & 0 & 10 & 11 & 12 & 13 & 14 & 15 & 16 & 17 & 18 \\
\hline $\begin{array}{c}\text { Func- } \\
\text { tion }\end{array}$ & $A(t)$ & 10000 & 5275.00 & 4885.00 & 4510.00 & 4150.00 & 3805.00 & 3475.00 & 3160.00 & 2860.00 & 2575.00 \\
\hline \multirow[t]{5}{*}{$P_{t}$} & $1 \%$ & 10000 & 7753.44 & 7491.17 & 7226.28 & 6958.75 & 6688.53 & 6415.62 & 6139.98 & 5861.58 & 5580.40 \\
\hline & $2 \%$ & 10000 & 8050.77 & 7811.96 & 7568.37 & 7319.92 & 7066.49 & 6807.99 & 6544.33 & 6275.39 & 6001.07 \\
\hline & $3 \%$ & 10000 & 8321.39 & 8105.80 & 7883.74 & 7655.02 & 7419.44 & 7176.79 & 6926.86 & 6669.43 & 6404.28 \\
\hline & $4 \%$ & 10000 & 8564.52 & 8371.46 & 8170.68 & 7961.86 & 7744.69 & 7518.84 & 7283.95 & 7039.66 & 6785.61 \\
\hline & $5 \%$ & 10000 & 8780.33 & 8608.74 & 8428.56 & 8239.38 & 8040.74 & 7832.16 & 7613.16 & 7383.21 & 7141.76 \\
\hline
\end{tabular}


End of Table 2

\begin{tabular}{|c|c|c|c|c|c|c|c|c|c|c|c|}
\hline Term & $\mathrm{t}$ & 0 & 10 & 11 & 12 & 13 & 14 & 15 & 16 & 17 & 18 \\
\hline \multirow[t]{6}{*}{$\begin{array}{c}\text { Func- } \\
\text { tion }\end{array}$} & $A(t)$ & 10000 & 5275.00 & 4885.00 & 4510.00 & 4150.00 & 3805.00 & 3475.00 & 3160.00 & 2860.00 & 2575.00 \\
\hline & $6 \%$ & 10000 & 8969.76 & 8818.29 & 8657.73 & 8487.54 & 8307.14 & 8115.92 & 7913.22 & 7698.36 & 7470.60 \\
\hline & $7 \%$ & 10000 & 9134.33 & 9001.46 & 8859.29 & 8707.17 & 8544.40 & 8370.23 & 8183.88 & 7984.47 & 7771.12 \\
\hline & $8 \%$ & 10000 & 9275.98 & 9160.08 & 9034.91 & 8899.73 & 8753.73 & 8596.05 & 8425.75 & 8241.83 & 8043.20 \\
\hline & $9 \%$ & 10000 & 9396.92 & 9296.33 & 9186.68 & 9067.17 & 8936.89 & 8794.90 & 8640.12 & 8471.42 & 8287.53 \\
\hline & $10 \%$ & 10000 & 9499.41 & 9412.49 & 9316.88 & 9211.70 & 9096.01 & 8968.74 & 8828.75 & 8674.77 & 8505.38 \\
\hline Term & $\mathrm{t}$ & 0 & 19 & 20 & 21 & 22 & 23 & 24 & 25 & 26 & 27 \\
\hline $\begin{array}{c}\text { Func- } \\
\text { tion }\end{array}$ & $A(t)$ & 10000 & 2305.00 & 2050.00 & 1810.00 & 1585.00 & 1375.00 & 1180.00 & 1000.00 & 835.00 & 685.00 \\
\hline \multirow[t]{10}{*}{$P_{t}$} & $1 \%$ & 10000 & 5296.40 & 5009.56 & 4719.86 & 4427.26 & 4131.73 & 3833.25 & 3531.79 & 3227.30 & 2919.78 \\
\hline & $2 \%$ & 10000 & 5721.26 & 5435.86 & 5144.75 & 4847.82 & 4544.95 & 4236.03 & 3920.92 & 3599.51 & 3271.68 \\
\hline & $3 \%$ & 10000 & 6131.18 & 5849.88 & 5560.15 & 5261.72 & 4954.34 & 4637.73 & 4311.63 & 3975.75 & 3629.79 \\
\hline & $4 \%$ & 10000 & 6521.39 & 6246.60 & 5960.82 & 5663.61 & 5354.51 & 5033.05 & 4698.73 & 4351.04 & 3989.44 \\
\hline & $5 \%$ & 10000 & 6888.23 & 6622.03 & 6342.52 & 6049.04 & 5740.88 & 5417.31 & 5077.56 & 4720.83 & 4346.26 \\
\hline & $6 \%$ & 10000 & 7229.19 & 6973.28 & 6702.03 & 6414.49 & 6109.71 & 5786.64 & 5444.18 & 5081.18 & 4696.40 \\
\hline & $7 \%$ & 10000 & 7542.82 & 7298.55 & 7037.17 & 6757.50 & 6458.26 & 6138.06 & 5795.46 & 5428.87 & 5036.61 \\
\hline & $8 \%$ & 10000 & 7828.68 & 7596.99 & 7346.77 & 7076.53 & 6784.68 & 6469.47 & 6129.05 & 5761.40 & 5364.33 \\
\hline & $9 \%$ & 10000 & 8087.09 & 7868.62 & 7630.48 & 7370.90 & 7087.97 & 6779.57 & 6443.41 & 6077.01 & 5677.62 \\
\hline & $10 \%$ & 10000 & 8319.05 & 8114.10 & 7888.64 & 7640.64 & 7367.84 & 7067.77 & 6737.68 & 6374.58 & 5975.18 \\
\hline Term & $\mathrm{t}$ & 0 & 28 & 29 & 30 & 31 & 32 & 33 & 34 & 35 & 36 \\
\hline $\begin{array}{c}\text { Func- } \\
\text { tion }\end{array}$ & $A(t)$ & 10000 & 550.00 & 430.00 & 325.00 & 235.00 & 160.00 & 100.00 & 55.00 & 25.00 & 10.00 \\
\hline \multirow[t]{10}{*}{$P_{\vec{t}}$} & $1 \%$ & 10000 & 2609.18 & 2295.47 & 1978.63 & 1658.61 & 1335.40 & 1008.95 & 679.24 & 346.24 & 9.90 \\
\hline & $2 \%$ & 10000 & 2937.29 & 2596.21 & 2248.30 & 1893.44 & 1531.49 & 1162.29 & 785.71 & 401.60 & 9.80 \\
\hline & $3 \%$ & 10000 & 3273.45 & 2906.42 & 2528.38 & 2139.00 & 1737.94 & 1324.85 & 899.36 & 461.11 & 9.71 \\
\hline & $4 \%$ & 10000 & 3613.37 & 3222.26 & 2815.51 & 2392.49 & 1952.55 & 1495.01 & 1019.16 & 524.29 & 9.62 \\
\hline & $5 \%$ & 10000 & 3952.96 & 3540.00 & 3106.38 & 2651.09 & 2173.03 & 1671.07 & 1144.02 & 590.61 & 9.52 \\
\hline & $6 \%$ & 10000 & 4288.53 & 3856.19 & 3397.90 & 2912.12 & 2397.20 & 1851.37 & 1272.80 & 659.52 & 9.43 \\
\hline & $7 \%$ & 10000 & 4616.91 & 4167.82 & 3687.29 & 3173.13 & 2622.98 & 2034.31 & 1404.44 & 730.48 & 9.35 \\
\hline & $8 \%$ & 10000 & 4935.50 & 4472.36 & 3972.17 & 3431.96 & 2848.54 & 2218.45 & 1537.94 & 803.00 & 9.26 \\
\hline & $9 \%$ & 10000 & 5242.29 & 4767.78 & 4250.57 & 3686.80 & 3072.30 & 2402.49 & 1672.40 & 876.60 & 9.17 \\
\hline & $10 \%$ & 10000 & 5535.83 & 5052.55 & 4520.94 & 3936.17 & 3292.93 & 2585.36 & 1807.03 & 950.87 & 9.09 \\
\hline
\end{tabular}

\subsection{Simulation of the changing trend of the interest rate}

Assuming that the term of lease is $t=36$ and the initial price of the leased items is $A=P_{0}=10000$, in the actual case, the investment of the financial leasing platform is then within three years, and the interval of the interest rate is between $5 \%$ and $10 \%$, we performed a simulation for the assets value function $P_{t}=R \cdot p_{n-t i}$ and the price of leased items function $A(t)=\left[A-\sum_{t=1}^{n} D_{\bar{t}}\right]$. The result is shown in Figure 4 . 


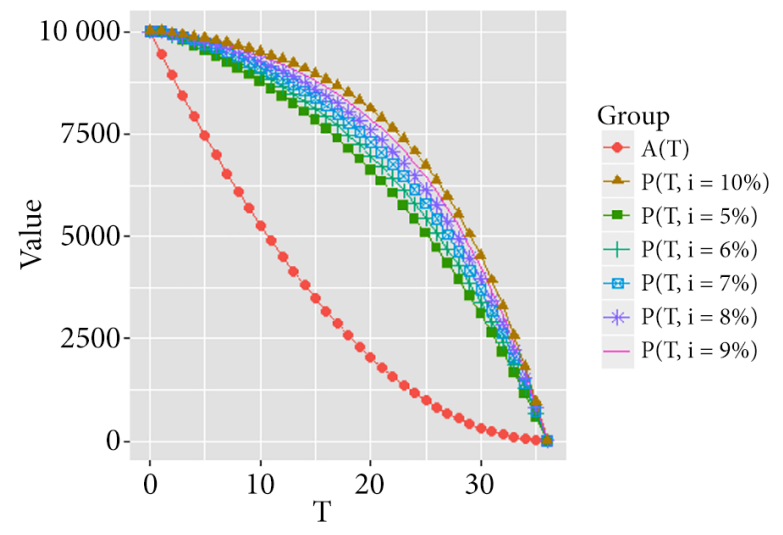

Figure 4. Simulation of the changing trend of parameters of the interest rate

Figure 4 shows that when the interest rate rises from $1 \%$ to $10 \%$, the value of leased assets also grows up with its growth, and with the increase of function curve radian shows that the gap between the value of leased assets and the price of leased items would be widening. It proves that two business modes with and without P2P financial leasing have different risks, the business model of financial leasing with P2P platform has more obvious business advantages to reduce the risk.

\subsection{Simulation of the changing trend in the parameters of the lease term}

The assumption was made that the initial price of the leased assets is $A=P_{0}=10000$ and the interest rate is $i=10 \%$. The lease term is set at $t=12, t=24$, and $t=36$, while the corresponding investments of the financial leasing platform are one-year, two-year, and threeyear, respectively. Based on this, we performed a simulation for the assets value function $P_{t}=R \cdot p_{\overline{n-t} i}$ and the function of the leased items $A(t)=\left[A-\sum_{t=1}^{n} D_{\bar{t}}\right]$. The result is shown
in Figure 5.

Figure 5 shows that it has the trend of widening the gap between the value of leased assets and the price of leased items when the lease term is extended from 12 terms to

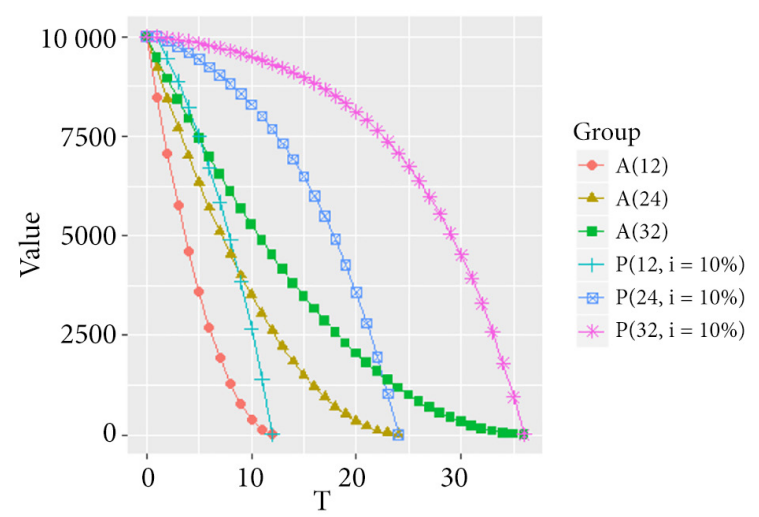

Figure 5. Simulation of the changing trend of parameters of the lease term 
36 terms. The widening gap implies the differences in the ability to take risks between the two business modes. As we know, the classical theory of interest rate risk describes that the longer the time, the higher the interest rate risk of the asset and the biggest function of $\mathrm{P} 2 \mathrm{P}$ is to diversify the risk of investment and avoid throwing eggs in one basket, thus the business mode with $\mathrm{P} 2 \mathrm{P}$ has better risk-taking ability than the business mode without P2P.

\subsection{Simulation of the changing trend in the parameters of the interest rates and the lease term}

Based on the assumption that the initial price of the leased assets is $A=P_{0}=10000$ and the interval of the interest rate is $[0.01,0.36]$, the term of the lease $t$ is set as a continuous variable with the interval of $[0,36]$. We performed a three-dimensional simulation that was multi-dimensional for the leased assets value function $P_{t}=R \cdot p_{n-t i}$ and the leased items function $A(t)=\left[A-\sum_{t=1}^{n} D_{\bar{t}}\right]$. The results are shown in Figures 6(a) and 6(b).

Since the initial price of the leased items and the value of the leased assets are equal, the lessee can buy the assets to have the ownership according to the residual value of the leased items when the business transaction is finished. At this time, the value of the price of the leased items corresponds to the value of the leased assets. Therefore, combining the changing trend of lease term and interest rate, we can simulate these two functions in threedimensional space as shown in Figure 7.

Figure 6 (a), 6 (b) and Figure 7, which results through practical data simulation and $3 \mathrm{~d}$ graphics surface simulation. Figure6 (a) illustrates the price of leased items $A(t)$ is monotone smooth declining, the surface shows a concave tendency of smoothness. And Figure 6 (b) shows the value of the leased assets $P_{t}$ on the surface present convex tendency, and with the increasing rate of return and terms, the curved surface of the crown is more obvious with the increase of interest rate and the lease term. Figure7(a) and Figure7(b) indicate that when the lease term is longer and the interest rate is higher, the difference between the two function surfaces is larger. Thus, the business model of financial leasing in the P2P platform has more obvious business advantages.

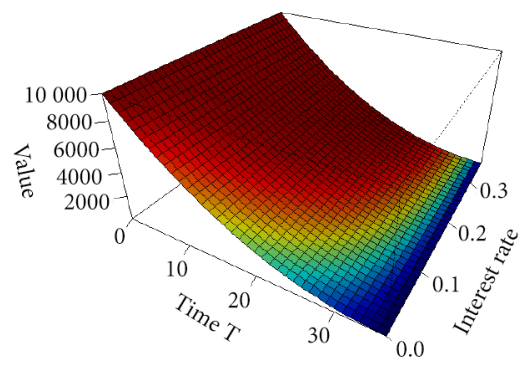

a)

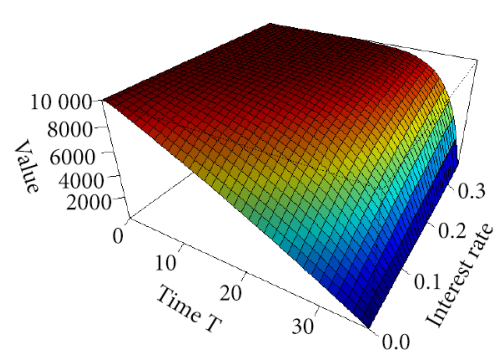

b)

Figure 6. Simulation of $A(t)(a)$; simulation of $P_{t}(b)$ 


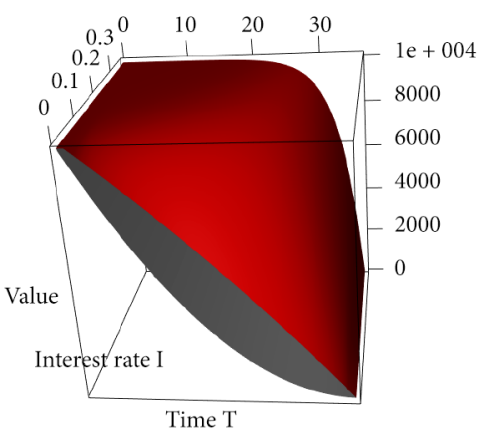

a)

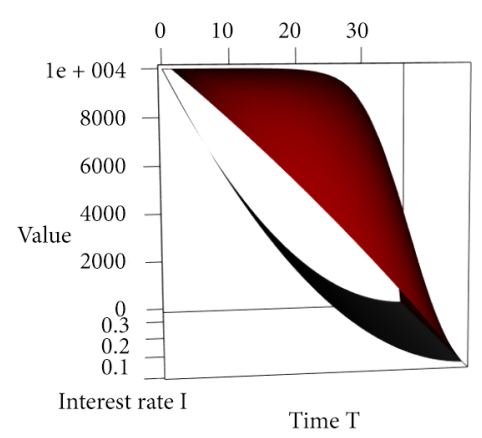

b)

Figure 7. Simulation of $A(t)$ (a); simulation of $P_{t}$ (b) in 3D modeling

\section{Conclusions}

Based on the preceding literature, this paper compares and summarizes three different financial leasing modes in the $\mathrm{P} 2 \mathrm{P}$ platforms, including the traditional mode, the assignment of proceeds mode, and the debt cession mode. The debt transfer mode, in particular, has the ability to resist risks, therefore reducing the degree of asset specificity and the transaction costs. Moreover, through the transfer of the creditor's rights, investors have reduced their limitations and promoted the conversion of current consumption into platform storage savings. The mode is important for market transactions because it provides the best economic characteristics.

From the perspective of the economic transaction process and transaction costs, this paper takes into account the difference between the leased assets value and the leased items price under the conditions of multi-period, variable, and continuous changes in the parameters of interest rate changes for reducing the risk of financing lease docking in the P2P platform. Our research model is more suitable for the P2P environment, with its many participants, than is the previous design of the financial leasing model, which involves a single cycle, discontinuous and fixed investments. This research result can be applied to solving the risk management problem of financial leasing and to guaranteeing the benefits of all participants in the P2P platform.

Through the equilibrium and dynamic analysis of microeconomics, the paper verifies that the value of the price function of the leased items is always lower than that of the value function of the leased assets. With the increase in the lease term $t$ and the higher interest rate $i$, the difference between these two functions has become steadily greater. The risk of the leased assets held by the P2P platform and the transfer through the creditor's right to invest is lower than for the traditional mode where the P2P platform includes mortgage-backed funding by investors, while the revenue of the platform remains unchanged.

As a result of leasing physical depreciation presents a trend of smooth decline, financing lease companies that hold the same lease can transfer creditor's rights through the P2P in the business of the actual financial leasing industry. In which way, the amount of funds obtained through $\mathrm{P} 2 \mathrm{P}$ debt transfer mode is higher than that obtained through mortgage. And the value of assets held by P2P platforms after the transfer of creditor's rights is higher 
than the price of real assets held by lease items. The business advantages of P2P platforms and financial leasing companies through the transfer of creditor's rights and asset securitization is significantly better than the way of obtaining funds through mortgage.

In theoretically, our research further verifies the classic conclusion of the Macaulay Duration Interest Rate Risk Theory that the longer the maturity of securities is, the lower the yield rate is and the higher the risk of interest rate is. And it broadens the application scope of risk utilization in financial leasing and P2P platforms. In practice, the emergence of debt cession in P2P platforms makes investors' funds more flexible and gives them more security and freedom in their choices. Clearly, there are now more and more long-term targets for online loan platforms. If a platform does not have the transfer of the creditor's rights, then investors cannot withdraw from the platform if they need funds, and they cannot withdraw from the project when they have security considerations. This seriously affects the experiences of investors. The debt cession mode can give investors the feeling that they are independent heads and the perception that their asset security is stronger than with the other modes. In addition, the cost of debt financing is low, and obtaining the financing is quick. The debt cession mode is also likely to give companies more tax breaks and can increase a firm's return on capital by reducing the total capital.

Due to the limitation of time and resources, there are still some places not explored in this paper. on the one hand, The fifth part of this paper refers to the benchmark interest rate of loan when defining the return rate of the assets in P2P platform, which is limited to the premise that the function return rate does not fluctuate randomly and the cash flow does not change with time within the term of securities. On the other hand, when the paper set the interest rate and the lease term variables and carried out the function simulation, it is assumed that the change of leased assets is within a certain period, and the factors such as term structure of interest rate, individual behavior of investors and breach of agreement have not been considered. Therefore, it is worth further study to enrich the hypothesis and improve the function curve simulation.

In addition to the above contributions, this study opens up several research opportunities for future work. It is well known that financial leasing business transactions often last for long periods of time, financial leasing companies invest large amounts of capital and have long recovery cycles, while the main targets of the Internet platform are small and medium investors, who have high requirements for the safety of the funds and for quick returns. The question of how to achieve an effective configuration within a specific time period is a valuable research issue. Meanwhile, the future work can consider the investor behavior, limited rationality and opportunity investment in economics, the influence of the term structure of interest rates on the pricing of the platform assets, and the fact that the expected return on platform assets may change along with changes in the benchmark lending interest rates and cross-border leasing rates.

\section{Funding}

This work was supported by the National Natural Science Foundation of China [grant number 71901075,71671048], the MOE Layout Foundation of Humanities and Social Sciences[ 
grant number 19YJCZH278], the Natural Science Foundation of Guangdong Province [grant number 2020A151501507] and Co-Construction Project of Philosophy and Social Science Planning Discipline in Guangdong Planning Office of Philosophy and Social Science [grant number GD18XGL37].

\section{References}

Azar, Y., Bartal, Y., Feuerstein, E., Fiat, A., Leonardi, S., \& Rosen, A. (1999). On capital investment. Algorithmica, 25(1), 22-36. https://doi.org/10.1007/PL00009281

Bachmann, A., Becker, A., Buerckner, D., \& Funk, B. (2011). Online peer-to-peer lending: A literature. Journal of Internet Banking and Commerce, 16, 1-18.

Ceyhan, S., Shi, X., \& Leskovec, J. (2011). Dynamics of bidding in a P2P lending service: Effects of herding and predicting loan success. In Proceedings of the 20th international conference on World wide web (pp. 547-556). ACM. https://doi.org/10.1145/1963405.1963483

Chen, X., Zhou, L., \& Wan, D. (2016). Group social capital and lending outcomes in the financial credit market: An empirical study of online peer-to-peer lending. Electronic Commerce Research and Applications, 15, 1-13. https://doi.org/10.1016/j.elerap.2015.11.003

Dai, W., Dong, Y., \& Zhang, X. (2016). Competitive analysis of the online financial lease problem. European Journal of Operational Research, 250(3), 865-873. https://doi.org/10.1016/j.ejor.2015.10.020

El-Yaniv, R., Kaniel, R., \& Linial, N. (1999). Competitive optimal on-line leasing. Algorithmica, 25(1), 116-140. https://doi.org/10.1007/PL00009279

El-Yaniv, R., \& Karp, R. M. (1997). Nearly optimal competitive online replacement policies. Mathematics of Operations Research, 22(4), 814-839. https://doi.org/10.1287/moor.22.4.814

Freedman, S., \& Jin, G. Z. (2017). The information value of online social networks: lessons from peerto-peer lending. International Journal of Industrial Organization, 51, 185-222.

https://doi.org/10.1016/j.ijindorg.2016.09.002

Fenwick, M., McCahery, J. A., \& Vermeulen, E. P. (2018). Fintech and the financing of SMEs and entrepreneurs: From crowdfunding to marketplace lending. In D. Cumming \& L. Hornuf (Eds.), The economics of crowdfunding (pp. 103-129). Palgrave Macmillan.

https://doi.org/10.1007/978-3-319-66119-3_6

Galloway, I. (2009). Peer-to-peer lending and community development finance. Community Investments, 21(3), 19-23.

Guo, Y., Zhou, W., Luo, C., Liu, C., \& Xiong, H. (2016). Instance-based credit risk assessment for investment decisions in P2P lending. European Journal of Operational Research, 249(2), 417-426. https://doi.org/10.1016/j.ejor.2015.05.050

Gao, G. X., Fan, Z. P., Fang, X., \& Lim, Y. F. (2018). Optimal stackelberg strategies for financing a supply chain through online peer-to-peer lending. European Journal of Operational Research, 267(2), 585-597. https://doi.org/10.1016/j.ejor.2017.12.006

Herrero-Lopez, S. (2009). Social interactions in P2P lending. In Proceedings of the 3rd Workshop on Social Network Mining and Analysis (p. 3). ACM. https://doi.org/10.1145/1731011.1731014

Herzenstein, M., Dholakia, U. M., \& Andrews, R. L. (2011). Strategic herding behavior in peer-to-peer loan auctions. Journal of Interactive Marketing, 25(1), 27-36.

https://doi.org/10.1016/j.intmar.2010.07.001

Karp, R. M. (1992, August). On-line algorithms versus off-line algorithms: How much is it worth to know the future?. In Proceedings of the IFIP 12th World Computer Congress on Algorithms, Software, Architecture - Information Processing '92 (Vol. 1, pp. 416-429). North-Holland Publishing Co. 
Janda, K., \& Svárovská, B. (2010). Investing into microfinance. Journal of Business Economics and Management, 11(3), 483-510. https://doi.org/10.3846/jbem.2010.24

Larrimore, L., Jiang, L., Larrimore, J., Markowitz, D., \& Gorski, S. (2011). Peer to peer lending: The relationship between language features, trustworthiness, and persuasion success. Journal of Applied Communication Research, 39(1), 19-37. https://doi.org/10.1080/00909882.2010.536844

Lee, E., \& Lee, B. (2012). Herding behavior in online P2P lending: An empirical investigation. Electronic Commerce Research and Applications, 11(5), 495-503. https://doi.org/10.1016/j.elerap.2012.02.001

Liang, Z., Wang, W., \& Li, S. (2012). Decomposition valuation of complex real options embedded in creative financial leases. Economic Modelling, 29(6), 2627-2631.

https://doi.org/10.1016/j.econmod.2012.09.001

Lin, M., Prabhala, N. R., \& Viswanathan, S. (2013). Judging borrowers by the company they keep: Friendship networks and information asymmetry in online peer-to-peer lending. Management Science, 59(1), 17-35. https://doi.org/10.1287/mnsc.1120.1560

Lin, X., Li, X., \& Zheng, Z. (2017). Evaluating borrower's default risk in peer-to-peer lending: evidence from a lending platform in China. Applied Economics, 49(35), 3538-3545. https://doi.org/10.1080/00036846.2016.1262526

Lotker, Z., Patt-Shamir, B., \& Rawitz, D. (2008a). Rent, lease or buy: Randomized algorithms for multislope ski rental. In Proceedings of the 25th Symposium on Theoretical Aspects of Computer Science (STACS). https://arxiv.org/abs/0802.2832

Lotker, Z., Patt-Shamir, B., \& Rawitz, D. (2008b). Ski rental with two general options. Information Processing Letters, 108(6), 365-368. https://doi.org/10.1016/j.ipl.2008.07.009

Ferreira, F. A. F., Spahr, R. W., Gavancha, I. F. M. D. (2013). Readjusting trade-offs among criteria in internal ratings of credit-scoring: An empirical essay of risk analysis in mortgage loans. Journal of Business Economics and Management, 14(4), 715-740. https://doi.org/10.3846/16111699.2012.666999

Milanesi, G. S. (2016). Simple and complex option valuation in financial leasing. Estudios Gerenciales, 32(138), 25-34. https://doi.org/10.1016/j.estger.2015.08.004

Puro, L., Teich, J. E., Wallenius, H., \& Wallenius, J. (2011). Bidding strategies for real-life small loan auctions. Decision Support Systems, 51(1), 31-41. https://doi.org/10.1016/j.dss.2010.11.016

Sonenshein, S., Herzenstein, M., \& Dholakia, U. M. (2011). How accounts shape lending decisions through fostering perceived trustworthiness. Organizational Behavior and Human Decision Processes, 115(1), 69-84. https://doi.org/10.1016/j.obhdp.2010.11.009

Wang, H., Greiner, M., \& Aronson, J. E. (2009). People-to-people lending: The emerging e-commerce transformation of a financial market. In Value creation in e-business management (pp. 182-195). Springer, Berlin, Heidelberg. https://doi.org/10.1007/978-3-642-03132-8_15

Yan, J., Yu, W., \& Zhao, J. L. (2015). How signaling and search costs affect information asymmetry in P2P lending: The economics of big data. Financial Innovation, 1(1), 19. https://doi.org/10.1186/s40854-015-0018-1

Yang, X., Zhang, W., Zhang, Y., \& Xu, W. (2012). Optimal randomized algorithm for a generalized skirental with interest rate. Information Processing Letters, 112(13), 548-551. https://doi.org/10.1016/j.ipl.2012.04.006

Zhao, H., Liu, Q., Zhu, H., Ge, Y., Chen, E., Zhu, Y., \& Du, J. (2018). A sequential approach to market state modeling and analysis in online p2p lending. IEEE Transactions on Systems, Man, and Cybernetics: Systems. https://doi.org/10.1109/TSMC.2017.2665038

Zhang, K., \& Chen, X. (2017). Herding in a P2P lending market: Rational inference OR irrational trust? Electronic Commerce Research and Applications, 23, 45-53.

https://doi.org/10.1016/j.elerap.2017.04.001 